\title{
PRAVDĚPODOBNOST DODRŽENÍ NÁKLADU゚ Z NÁVRHU VE VÝSTAVBĚ V ČR
}

\author{
PROBABILITY OF KEEPING THE DETAILED ESTIMATE OF CONSTRUCTION COST \\ IN THE CZECH REPUBLIC
}

Ing. Stanislav Vitásek

\begin{abstract}
ABSTRAKT
Článek se zabývá výpočtem statistických ukazatelů a pravděpodobnosti dosažení plánovaných nákladů z návrhu stavebního díla, při použití obvyklých nástrojů pro ocenění stavební produkce v ČR. Výpočet statistických veličin, je založen na datové základně třiceti bytových domů realizovaný dvanácti stavebními firmami. Sedmdesát procent bytových domů bylo dokončeno v roce 2015 a zbylé v roce 2014. Dále se článek věnuje rizikům, která mají největší vliv na pohyb skutečně dosažených nákladů oproti návrhu. Konkrétní rizika se získala od zástupců předních stavebních firem v ČR, pomocí Delfské metody. Článek tedy přináší reálný obraz práce s náklady v českém stavebním prostředí, určený primárně stavebním firmám pro jejich cenovou (obchodní) strategii spolu s návrhy na zvýšení pravděpodobnosti dosažení plánovaných nákladů z návrhu stavebního díla v samotné výstavbě.
\end{abstract}

Klíčová slova: Náklady, statistika, stavebnictví.

\section{ABSTRACT}

The article is about statistical index calculations and about the determination of the detailed estimate cost precision of the construction, while using the usual tools to estimate the price for the development in CZ. Statistical input calculations are based upon the data basis of thirty apartment buildings, constructed by twelve different developers. Seventy percent of the apartment buildings were finished in the year 2015 and the rest in 2014. Furthermore, the article discusses the risks detected by the Delphi Method, and in cooperation with the representatives of the main developing companies in CZ. The article, therefore brings the realistic view, how we work with the costs in Czech development industry and its determined primary for the developers, to help them with the economic strategy, and with the proposals, how to increase the probability of meeting the detailed estimate of construction cost.

Key words: Construction, Estimate Cost, Statistics.

\section{1 ÚVOD}

Každá stavební firma chce mít plně pod kontrolou svoje náklady, aby mohla co nejlépe fungovat. Na rozdíl od ostatních odvětví průmyslu, je ve stavebnictví každý produkt (stavební dílo) unikát a stanovit přesně jeho cenu ve fázi návrhu je velmi obtížné. Ani za použití nejmodernějších nástrojů není téměř možné dosáhnout přesně sta procent plánovaných nákladů po samotném konci výstavby. Můžou se však hledat cesty, které pomohou se $\mathrm{k}$ tomuto číslu, co nejvíce přiblížit. V článku se pracuje s aktuálními daty právě dokončených bytových domů, kde většina těchto objektů byla uvedena do provozu v roce 2015 a zbylé v roce 2014. Jedná se o třicet bytových domů, realizovaných dvanácti společnostmi. Potřebná data se zajistila od předních představitelů stavebních firem v ČR. Spolu s poskytnutými informacemi o nákladových cenách stavebních objektů z návrhu a po dokončení, se 
vybraní zástupci vyjádřili k rizikům, která nejvíce ovlivňují nákladovou cenu z návrhu v samotné realizaci stavebního díla. České stavební firmy nebyly př́liš ochotné uvolňovat tato citlivá data, ale nakonec podlehly tlaku akademické obce. Získaná data se zpracují pomocí různých statistických technik, které reálně mapují aktuální stav práce s náklady v ČR.

Článek se výhradně zabývá nákladovou cenou z pohledu generálního dodavatele stavebního díla $\mathrm{v}$ soukromém sektoru. Nákladová cena stavebního díla je termín reprezentující celkové náklady na výstavbu s přiměřeným ziskem pro zhotovitele. Jedná se pouze o náklady ze stavební činnosti budoucího objektu, bez koupě pozemku, odvodů daní atd. [1] V tomto výzkumu se aplikovaly právě nákladové ceny, které sloužily jako podklad pro smlouvu o dílo.

\section{STATISTIKA A NÁKLADOVÁ CENA ZA STAVEBNÍ DÍLO}

Pomocí statistických údajů se nejlépe analyzuje aktuální stav této problematiky v ČR. Data pro analýzu českého trhu poskytlo dvanáct středně velikých stavebních firem s ročním obratem do 15000 $000 €$ ročně, celkem pro třicet objektů. Jedná se o bytové domy s rozsahem obestavěného prostoru od $5000 \mathrm{~m}^{3}$ do $13000 \mathrm{~m}^{3}$, které byly zkolaudované v letech 2014 a 2015 . V cenovém rozmezí od 700 $000 €$ do něco málo přes $2000000 €$. Konstrukční systém drtivého množství objektů je založen na monolitickém betonovém skeletu vyplněném keramickými tvárnicemi s plochou střešní konstrukcí.

\begin{tabular}{|c|c|c|c|c|}
\hline \multicolumn{5}{|c|}{ Dosažená hodnota nákladové ceny z návrhu [\%] } \\
\hline 75,52 & 84,01 & 105,00 & 85,02 & 88,01 \\
\hline 95,01 & 90,99 & 84,00 & 104,00 & 87,00 \\
\hline 94,02 & 84,01 & 88,00 & 114,99 & 102,99 \\
\hline 95,00 & 85,99 & 83,00 & 94,00 & 93,99 \\
\hline 85,00 & 83,00 & 84,01 & 106,02 & 92,01 \\
\hline 88,99 & 88,00 & 96,00 & 92,01 & 94,01 \\
\hline
\end{tabular}

Tab. 1 Procentuální vyjádření dodržení nákladové ceny z návrhu

Tabulka č. 1 shrnuje výsledky z údajů poskytnutých stavebními firmami. $Z$ výše získaných dat je zrejmé, že stavebním společnostem se daří umístovat do svých rozpočtů značné rezervy. Např́íklad pokud nákladová cena z návrhu byla $925000 €$ a po realizaci $740000 €$, došlo k $80 \%$ naplnění nákladů z návrhu. Záleží pak dále na smluvních podmínkách mezi investorem a generálním dodavatelem, jak se s těmito rozdíly mezi sebou vypořádají. Pouze v pěti případech $\mathrm{z}$ třiceti došlo k překročení nákladové ceny z návrhu. Dále u třinácti objektů z třiceti, tedy každý třetí př́esáhnul nákladovou cenu z návrhu o více jak $10 \%$. A samotný aritmetický průměr všech dosažných nákladových cen z návrhu (tab. 1) je okolo $92 \%$. 


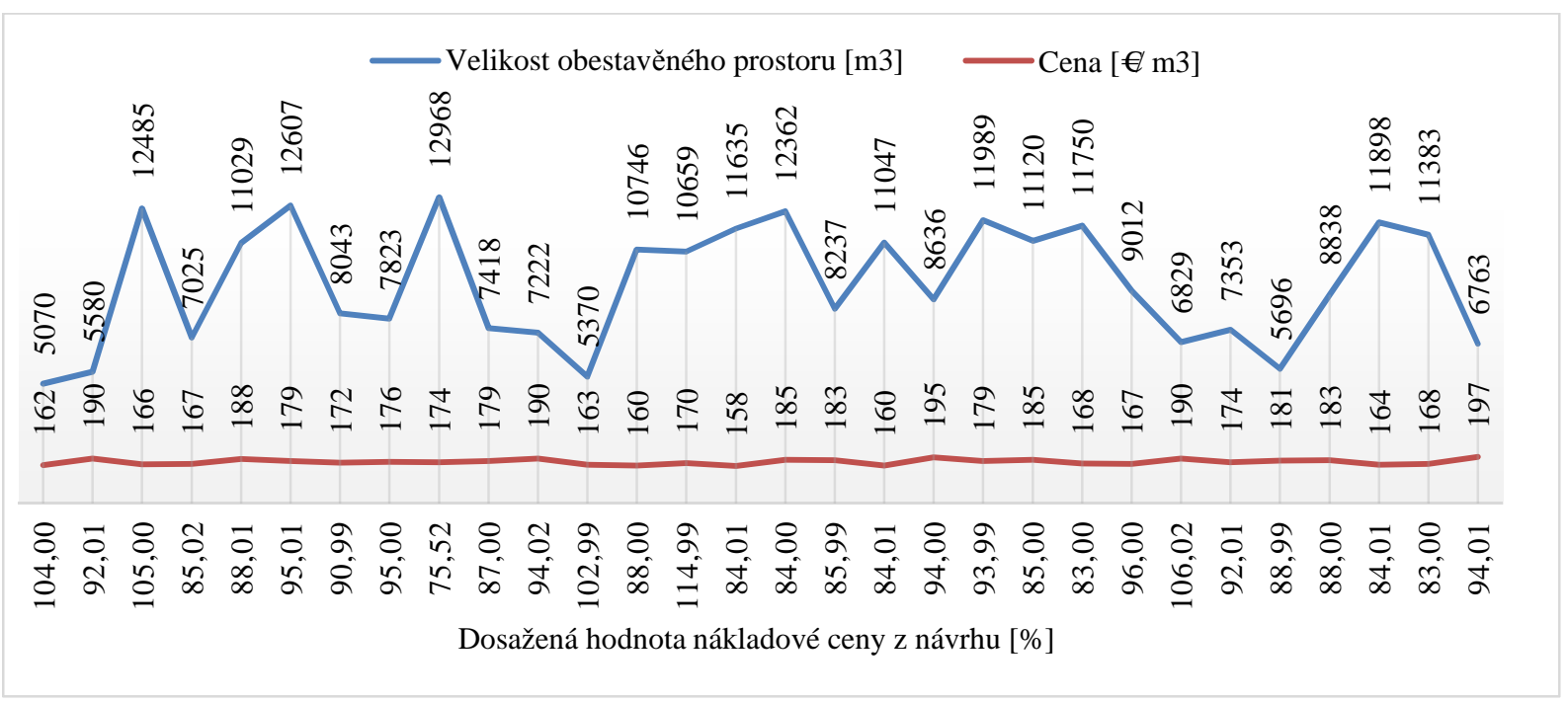

Obr. 1 Závislost dodržení nákladů z návrhu na velikosti obestavěného prostoru

Závislost dosažené procentuální hodnoty z návrhové nákladové ceny na velikosti objektu stanovených podle $\mathrm{m}^{3}$ obestavěného prostoru zobrazuje obrázek výše (obr. 1). Ze získaných dat vyplývá, že při větším objemu obestavěného prostoru bytového domu klesá procentuální hodnota dodržení nákladové ceny z návrhu. Jednoduše tedy čím je objekt „,ětší“, tím je dosažená procentuální hodnota nákladové ceny z návrhu nižší. Obrázek č. 1 také uvádí kř̌ivku s peněžně vyčíslenými údaji o ceně za $1 \mathrm{~m}^{3}$ obestavěného prostoru. $Z$ těchto dat se dá vyčíst, že cena za $1 \mathrm{~m}^{3}$ bytového zděného domu nemá př́mou spojitost $\mathrm{s}$ velikostí objektu a pohybuje se v průměru okolo $176 €$.

Přesnost dodržení nákladů z návrhu se vyhodnocuje jako ukazatel správné práce s náklady jakékoli stavební firmy. Zatím není v ČR žádná obecně platná pevná hranice, která určuje, jaké dosažené hodnoty jsou brány jako akceptovatelné a jaké nikoli. Správným cílem pro české stavebnictví je se co nejblíže přiblížit +- $5 \%$ rozdílu mezi cenami z návrhu a po dokončení stavebního díla. Tato hranice je vnímána $\mathrm{v}$ mezinárodních publikacích, jako známka profesionálního př́́stupu $\mathrm{k}$ plánování a samotnému řízení nákladů stavebního díla pro tento druh pozemního stavitelství. [2]

\section{RIZIKA A NÁKLADOVÁ CENA ZA STAVEBNí DÍLO}

Stavební praxe na území ČR má svoje unikátní rizika, s kterými se musí více či méně počítat při sestavování nákladové ceny. Jejich ocenění a zahrnutí do samotné smlouvy o dílo je individuální a každá firma má svůj systém, jak s nimi pracovat. [3] Tato kapitola je věnována identifikaci právě takových rizik, které nejvíce ovlivňují rozdíl mezi nákladovou cenou z návrhu a skutečně dosaženou. Obvykle se rizika představují jako hrozba negativně ovlivňující výsledek projektu. V článku se pracuje s riziky tak, že mohou ovlivnit projekt i v opačném směru. Tedy, reálná nákladová cena po zhotovení objektu může mít nižší hodnotu než nominální cena z návrhu.

Konkrétní výběr rizik se provedl pomocí delfské metody. Tato expertní metoda spočívá v obeslání skupiny odborníků s hledáním odborného řešení nezávisle na sebe. Do průzkumu se zapojili odborníci z řad stavebních firem, kteři poskytli data pro výpočet statistických údajů (2. kapitola). Respondenti měli zmapovat a vyhodnotit nejčastější rizika spojená s dodržováním nákladů z návrhu díla ve výstavbě. Vybraným rizikům hodnotitelé prriřadili velikosti dopadu od hodnoty 1 až 10 , tedy od zanedbatelného dopadu až po neprrijatelný a procentuální pravděpodobnost jejich výskytu. [4] Na základě získaných odpovědí se bylo možné vymezit na pět nejvýznamnějších rizik:

- $\quad$ Nedostatečná projektová dokumentace 
- Chybně sestavený stavební rozpočet

- $\quad$ Nedodržení či nejasnosti podmínek ve smlouvě o dílo

- Vznik více prací nebo méně prací

- $\quad$ Subdodavatelé

Výsledky průzkumu jsou shrnuty níže v obrázku č. 2, kde se sestavilo maticové ohodnocení rizik. Jako rizika s největším podílem na změně ceny z návrhu se identifikoval chybně sestavený rozpočet a práce se subdodavateli. Riziko chybně sestaveného rozpočtu, at' už chybou kalkulace nebo vlivem nesprávně sestaveného výkazu výměr, vede k chybným objednávkám během realizace, zmatečním procesům při vykazování práce, zkreslení cen a k nežádoucím zvýhodněním jedné nebo druhé strany.

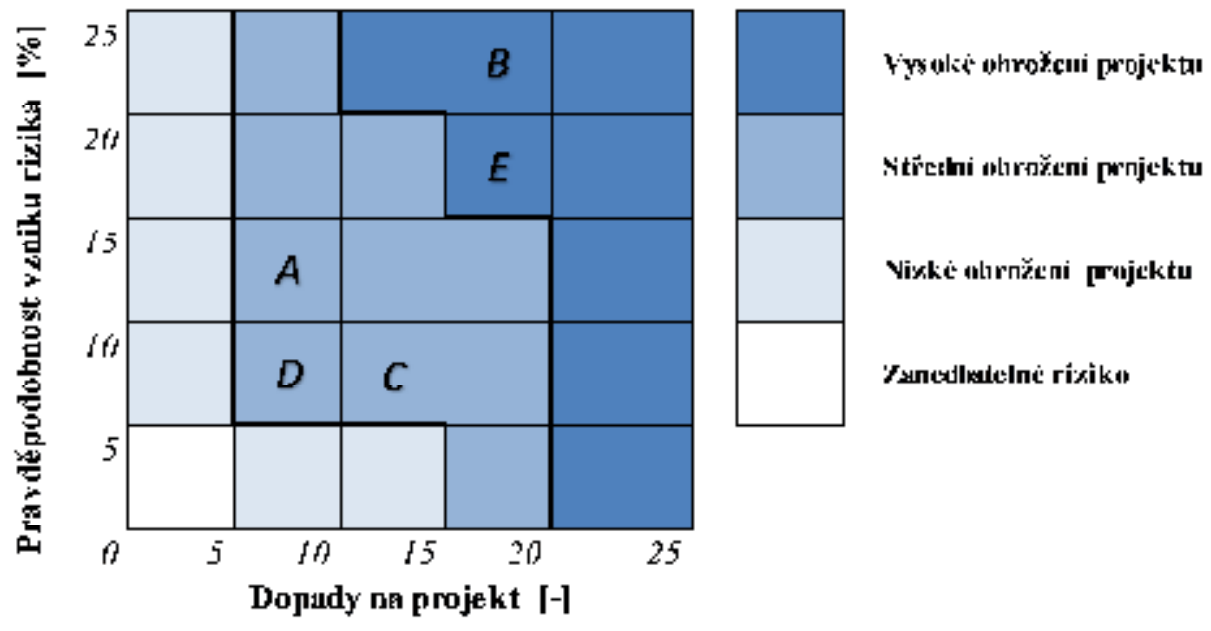

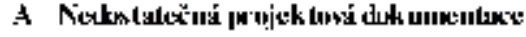

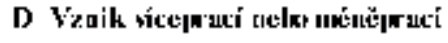

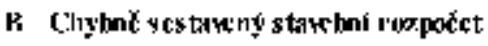
F. Subdoukatalc

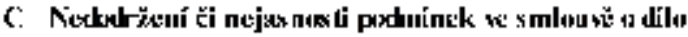

Obr. 2 Matice rizik

Druhým nejzásadnějším rizikem je práce se subdodavateli. Většina středně velkých firem v ČR realizuje obvykle větši část díla právě za pomoci subdodavatelů. Subdodavatelské firmy generální zhotovitel stavby najímá na práce, které není schopen zabezpečit z vlastních zdrojů, at' už kvưli kapacitě či absenci potřebné kvalifikace. Jedná se většinou o řemeslnické činnosti. Přri realizaci v praxi běžně dochází k opětovnému poptání subdodavatelů, tedy do realizace. Výsledkem takového procesu je obvykle snížení nákladové ceny z návrhu.

\section{ZÁVĚR}

Přesnost stanovení nákladů z návrhu a pak samotné dodržení je ukazatel správné práce s náklady jakékoli stavební firmy. Provedený výzkum z databáze třiceti bytových domů určil, že aritmetický průměr dosažení nákladů z návrhu je okolo $92 \%$. Další statistický údaj přinesl zjištění, že při větším objemu obestavěného prostoru bytového domu klesá procentuální hodnota dodržení nákladové ceny z návrhu. Na nadsazenost směrných cen z cenových soustav a špatné firemní kalkulaci poukazují data, o přesáhnutí nákladové ceny z návrhu o více jak $10 \%$ u každého třetího objektu. Posledním důležitým číslem je částka $176 € / \mathrm{m}^{3}$ obestavěného prostoru, kde se neprokázala přímá spojitost ceny za $\mathrm{m}^{3} \mathrm{~s}$ velikostí objektu. Tyto ukazatele reflektují reálnou práci s náklady středně velikých stavebních firem $\mathrm{v}$ ČR. Samozřejmě stanovit samotnou hranici prrípustných odchylek je velice obtížné a plošně neaplikovatelné. Správným cílem je pro české stavebnictví, co nejblíže se přiblížit +- 5 \% rozdílu mezi 
cenami z návrhu a po dokončení stavebního díla. Tak jak je tomu ve vyspělých zemích. Na druhou stránku dosahovat přes $90 \%$ průměr dodržení nákladové ceny z návrhu vzhledem ke všem rizikům není úplně nejhorší. S přibývajícím tlakem na optimalizaci nákladů a konkurenci je zřejmé, že procentuální odchylka od nákladové ceny z návrhu se bude dále snižovat.

Návrhy opatření souvisejí s aplikací dostupných nástrojů, které mají za cíl snížit pravděpodobnost nedodržení nákladů z návrhu, jsou bohužel zatím málo rozšířené. Chybovost ve stavebních rozpočtech představuje ideálního zástupce pro využití komplexních nástrojů založených na Build information modeling (BIM). Generování výměr spolu s odkazováním stavebních prvků na příslušné cenové soustavy, zatím spíše v různých agregátech, podstatně ulehčuje a zpřesňuje kalkulantům jejich práci. Tedy i náklady za stavební dílo. Druhým nejvíce rizikovým faktorem se vyhodnotila práce se subdodavateli. Bohužel při výběru vhodného subdodavatele na vybrané stavební činnosti je stále převažujícím kritériem nejnižší cena za provedené práce. Možné řešení spočívá v akceptování vyšších cen za provedené práce, které by reálně mohly dosáhnout nákladové ceny z návrhu a přinést do stavebního procesu kvalitní subdodavatele. A dále spolupracovat s firmami, s kterými máme dlouhodobě dobré zkušenosti.

Největší př́ínos pro přesnost stanovení samotných nákladů v návrhu díla si slibuji od modelů založených na BIM. Zapracováním této technologie se zvýší kromě přesnosti stanovení nákladů v návrhu díla i konkurenceschopnost a věrohodnost $\mathrm{v}$ očích investora. Bohužel ještě stále $\mathrm{v}$ ČR chybí dosti reprezentativních vzorků na kvalitně provedený výzkum a potvrzení hypotézy o eliminaci dominantního faktoru, tedy chyby ve stavebním rozpočtu.

\section{Poděkování}

Tato práce vznikla za podpory grantu z Českého vysokého učení technického v Praze, grant č. SGS16/026/OHK1/1T/11.

\section{Použitá literatura}

[1] WHYTE, Andrew. Integrated design and cost management for civil engineers. Boca Raton: CRC Press/Taylor, 2015. ISBN 978-041-5809-214.

[2] BALDWIN, A, Ronald MCCAFFER a Sherif OTEIFA. International bid preparation. Geneva: International Labour Office, 1995. ISBN 92-210-8752-2.

[3] RISK MANAGEMENT FOR DESIGN AND CONSTRUCTION CRETU, Ovidiu, Robert STEWART a Terry BERENDS. Risk management for design and construction. Hoboken, N.J.: RSMeans, c2011. ISBN 04-706-3538-X.

[4] WILLIAMS, Peter. Managing measurement risk in building and civil engineering. Hoboken, NJ: John Wiley, 2015. ISBN 978-111-8561-522. 